\title{
Precariousness, flexibility, and labor relations in the Fashion Industry
}

\author{
Precariedade, flexibilidade e relações de trabalho na Indústria da Moda \\ Precariedad, flexibilidad y relaciones laborales en la Industria de la Moda
}

Received: 12/02/2020 | Reviewed: 12/09/2020 | Accept: 01/01/2021 | Published: 04/01/2021

\author{
Fabiano Eloy Atílio Batista \\ ORCID: https://orcid.org/0000-0001-7067-560X \\ Universidade Federal de Viçosa, Brazil \\ E-mail: fabiano.batista@ufv.br \\ Glauber Soares Junior \\ ORCID: https://orcid.org/0000-0001-9902-9740 \\ Universidade Federal de Viçosa, Brazil \\ E-mail: glauber.junior@ufv.br \\ Isadora Franco Oliveira \\ ORCID: https://orcid.org/0000-0001-6403-358X \\ Universidade Federal de São João del Rei, Brazil \\ E-mail: isadorafrnco@gmail.com
}

\begin{abstract}
In this work, we carry out a reflection around issues regarding work in the Brazilian fashion and clothing industry one of the oldest activities performed by mankind. The objective of conceiving such work was to be able to understand the main aspects related to precariousness and inhuman work in this field. As far as the methodology applied to the study goes, this research is characterized as qualitative, and of descriptive and bibliographic type. As a result, in general, it can be observed that the precarious and flexible working relationships are utilized by companies as a means of profitability. However, when using this mechanism, worker's rights, which are the most fragile part of this process, are the most affected, and in many cases, workers find themselves in situations similar to slavery, working in a forced way, with exhaustive workdays, and in degrading conditions.
\end{abstract}

Keywords: Labor; Precariousness; Fashion industry; Brazil.

\section{Resumo}

Realizou-se, neste trabalho, uma reflexão ao redor das questões no que diz respeito ao trabalho na indústria de moda e de confecções brasileira, sendo esta uma das atividades mais antigas realizadas pelo homem. O objetivo de conceber tal trabalho foi o de se poder compreender os principais aspectos relacionados à precarização e ao trabalho desumano neste setor. No que diz respeito à metodologia utilizada no trabalho, o estudo se caracteriza como de natureza qualitativa, do tipo descritivo bibliográfico. Em relação aos principais resultados alcançados, evidencia-se que em linhas gerais, pode-se observar que a precarização e flexibilização das relações de trabalho são utilizadas pelas empresas como artifícios de lucratividade. Porém, quando se utiliza desse mecanismo, o direito dos trabalhados, que é a parte mais frágil desse processo, é a mais afetado, e em muitos dos casos, os trabalhadores encontram-se em situações análogas a escravidão, trabalhando de maneira forçada, com jornadas exaustivas e em condições degradantes.

Palavras-chave: Trabalho; Precarização; Indústria da moda; Brasil.

\section{Resumen}

En este trabajo se reflexionó sobre las cuestiones relativas al trabajo en la industria de la moda y la confección de Brasil, siendo ésta una de las actividades más antiguas realizadas por el hombre. El objetivo de concebir ese trabajo era poder comprender los principales aspectos relacionados con la precariedad y el trabajo inhumano en este sector. En cuanto a la metodología utilizada en el trabajo, el estudio se caracteriza por ser de carácter cualitativo, de tipo descriptivo bibliográfico. En relación con los principales resultados obtenidos, es evidente que en líneas generales se observa que la precariedad y la flexibilización de las relaciones laborales son utilizadas por las empresas como artificios de rentabilidad. Sin embargo, cuando se utiliza este mecanismo, el derecho de los trabajadores, que es la parte más frágil de este proceso, es el más afectado, y en muchos casos, los trabajadores se encuentran en situaciones análogas a la esclavitud, trabajando de manera forzada, con viajes exhaustivos y en condiciones degradantes.

Palabras clave: Trabajo; Precarización; La industria de la moda; Brasil.

\section{Introduction}

Due to being one of the oldest activities performed by mankind, the textile and clothing field is considered one of the 
most important ones within the Brazilian productive sector. According to data from the Brazilian Textile and Apparel Industry Association - ABIT (2019), the sector represents about $16.7 \%$ of jobs in the country; it is considered to be the largest complete textile chain in the West Hemisphere; the second-largest employer in the manufacturing industry, second only to food and beverages together; it is also the second-largest generator of first jobs, among other peculiarities that demonstrate its national importance and relevance.

However, the various efforts of capitalism towards greater profitability and the lowest possible capital expenditure have demanded greater flexibility from the fashion production chain, which, within labor issues, translate into precariousness and reformulation of employer-employee relations, significantly changing work relationships and turning them into real puzzles. As a result, this flexibility divides the functions within the fashion segment that were previously concentrated in a single company and is now subdivided into other outsourced companies, individuals, and temporary jobs, therefore, reflecting in a decrease in labor rights, expansion of production, reduction of costs and increase of profits for companies - that is, holders of capital (Harvey, 2010; Antunes, 2009; Antunes \& Druck, 2015).

According to Antunes (2009), it is, in fact, a process of work organization in which the real and essential purpose is to intensify the conditions for exploiting the workforce, greatly reducing or eliminating both the unproductive work that does not create value and its similar forms, especially in activities such as maintenance, monitoring, and quality inspection, functions that are now directly incorporated into the productive employee. Reengineering, lean production, teamwork, elimination of jobs, increased productivity and total quality are part of the idea and the everyday practice of a "modern factory". If in the heyday of Taylorism/Fordism the strength of a company was measured by the number of workers who performed its work activity in it. One may say that, in the era of flexible accumulation and "lean companies", businesses that have higher productivity indexes, despite having a smaller contingent of the workforce, are examples to be followed and worth mentioning.

\section{Methodology}

This study, as it relates to questions about work in the fashion industry, seeks to broaden the perspective on this theme, based on a literature review. In order to accomplish that, as far as the methodology goes, we use in this study a qualitative approach, of bibliographic and descriptive nature, through which we seek to gather researches and information that reflect and discuss labor issues in the fashion industry for a deeper understanding of how this reality has been problematized.

As presented by Godoy (1995), there are three ways of studying a phenomenon from a qualitative point of view, these being a) documentary research, b) case study, and c) ethnography. In this study, we chose to apply documentary research, because, according to the author, this type of research can be based on numerous sources, such as newspapers, magazines, scientific articles, books, images, among others, enabling the work to be carried out with creativity. Documentary analysis is an important source of information because it is non-relative, meaning that the information found in documents will remain the same over time. Besides, the documents are considered rich sources of information, as they can deal with data that has not yet been processed or that can be revisited by analyzing with new perspectives and different interpretations.

Regarding the choice for descriptive research, Gil (2008) says it is evident that these researches are carried out with the main intention of describing the main characteristics of a given phenomenon. It should be noted that the choice for bibliographic research was due to the fact that, in many cases, there are no other possibilities to understand past events other than the use of secondary data (Gil 2008). So, in this perspective, in many studies, the use of secondary data will be the most viable option to achieve its objectives.

Researches from secondary sources, as explained by Barros, Rosa \& Ribeiro (2017), are built from the analysis and reorganization of the analytical material - magazines, newspapers, books, articles, among others - previously selected. The bibliographic research conducted was based on the studies by Motta, Roth \& Hendges (2010). According to the authors, the 
bibliographic survey is essential in all types of scientific work, in addition to enabling the researcher to have a macro perspective on the subject studied. Among other relevant matters, the bibliographic research: a) shows the establishment of the research field studied, also pointing out its gaps; b) supports the literature review based on the use of renowned authors.

\section{Results and Discussion}

Through globalization, the production chains of different sectors of the economy have undergone profound changes. Thus, in a capitalist society, large companies - essentially those in the field of fashion and clothing -, aiming to reduce costs in the production process, begin to exploit their employees. Since efforts cannot be measured in search of profitability, those actions lead to an emergence of increasingly precarious jobs. In this context, although slavery officially ended more than a century ago in Brazil, the workforce continues to be exploited in the country, but in different ways (Silva \& Silveira, 2018).

Batista (2018) reflected in his work that the fashion industry - taken as an extensive productive chain - operates with working conditions that exploit the individuals in its production process, in such inhumane ways that the labor practices can be characterized as "analogous to slavery" - or, as defined by Miraglia, Hernandez, \& Oliveira (2018), "contemporary slavery labor". Although, Batista (2018) emphasizes that even though the work mode currently differs from its former slave origins, it is necessary to rethink the true working conditions that are exercised in Brazil, especially in the fashion industry. The current work mode differs from its slave origins in the sense that now the term given to the individual as possession or property has changed - formerly slave and now worker, peon, laborer. The applicability of their work, formerly in the field or doing domestic work and today in the transformation industry, civil construction or textile industries. Finally, it has also changed in the sense of the quality of life that is offered to them.

Corroborating such reflections, Santos (2017) emphasizes that in the globalized world, illegal work practices are found on a large scale in the fashion production chain, and may be present in the cotton harvesting process, in the spinning of the fiber in yarns, in the sewing of clothes and the final production process.

Even though slave labor is not recognized by the capitalist production model, as previously discussed, capitalism accepts it as a way of extracting surplus value, calling it "freestanding" work. In this regard, the lives of workers are commodified within the labor process, and outsourcing and flexibility (important spheres of the capitalist sector), in many cases, favor an expansion of inhuman working conditions (Batista, 2018).

According to Refosco \& Pessoa (2013) several companies apply this type of production - outsourced and flexible - in order to reduce production costs, eliminate equipment maintenance expenses, and lower taxes, charges, and duties payments, among other advantages.

To better understand the implications of the work analogous to slavery, Manduca \& Navarro (2019) point out some of its relevant characteristics, such as:

a. Forced labor is characterized by the individual's submission to conditions in which they are exploited, have their documents retained, suffer psychological pressure, physical violence, and stay put in places of difficult access or geographically isolated, as ways to coerce them into service.

b. Exhausting workdays are characterized by long working hours that go far beyond overtime, endangering the physical and mental integrity of the worker, in addition to having their coffee or lunch breaks rigorously controlled and their weekly time off or downtime not respected, keeping them from having social and family time.

c. Debt servitude is characterized by the obligation to work in order to pay off debts acquired from transportation, food, work tools, and housing. Those items are improperly charged and deducted from the salary, which, in many 
cases, the employee has all of their salary withheld in payment of debts.

d. Degrading conditions are characterized by a set of elements in which the employee is subjected, from precarious accommodation - that in many cases is the same place for the whole family and in which during the day is also the workspace - to poor nutrition, mistreatment, and lack of hygiene and drinking water.

Such working conditions have intensified since the end of the 20th century in the field of fashion, especially after the emergence of the commercial model known as fast fashion. By means of the latter, employees are conditioned to inhuman and exhaustive forms of work for fast and continuous production of garments in short periods of time - which consequently affects the entire production chain. This way, as Harvey (2010) says, we need to understand that the labor market has undergone a drastic restructuring. In the face of strong market volatility, increased competition, and narrowed profit margins, employers took advantage of the weakening of union power and a large amount of labor (unemployed and underemployed) to impose more flexible regimes since the purpose of this flexibility is to satisfy the very specific need of each company.

However, going against this reality and being considered an alternative to eradicate or minimize the damages of fast fashion, the slow fashion movement has been proposed as a sustainable and conscious way out regarding the fashion industry. This movement seeks appreciation based on values concerning sustainability and prioritizes the human condition of each individual that participates in the productive chain of the fashion industry (Duarte, 2015; Santos, 2017).

The reality about inhuman and precarious work in the Brazilian fashion industry arises, to a large extent, as a result of hiring foreigners (especially Latin Americans - from Bolivia and Peru), who, in search of improvement in their living conditions, come to Brazil (more specifically the São Paulo region) with false ideas of better opportunities. However, they face another reality when they arrive in the country, and, as a result, suffer from a series of physical and psychological forms of violence, along with being exploited and working in degrading conditions.

According to studies from Batista (2018), between the years of 2010 and 2014, several companies in the fashion field were filed suit for providing jobs in which conditions were similar to slavery, as we can see in the table below.

Table 1. Inhumane work cases in the fashion industry notified between 2010 and 2014.

\begin{tabular}{|c|c|c|}
\hline $\begin{array}{l}\text { Company Marisa and other cases in } \\
\text { the same year of notification }-2010\end{array}$ & $\begin{array}{l}\text { Company M. Officer and other cases } \\
\text { in the same year of notification }-2013\end{array}$ & $\begin{array}{c}\text { Company Renner and other } \\
\text { cases in the same year of } \\
\text { notification - 2014 }\end{array}$ \\
\hline $\begin{array}{l}\text { Marisa, a major retailer in Brazil, was } \\
\text { filed in March } 2010 \text { at a } \\
\text { manufacturing unit in São Paulo for } \\
\text { employing people in conditions that } \\
\text { were similar to slavery. During the } \\
\text { inspection, } 16 \text { Bolivians were found, } \\
\text { including one under the age of } 18 \text {, who } \\
\text { was not provided with a formal } \\
\text { contract. According to inspection } \\
\text { reports, notebooks containing illegal } \\
\text { expenses relating to the Bolivian } \\
\text { workers were also found. Two other } \\
\text { companies were filed in the same year: } \\
\text { Collins and } 775 \text {. }\end{array}$ & $\begin{array}{l}\text { In November 2013, a factory in the } \\
\text { central region of São Paulo was found } \\
\text { employing workers in a condition } \\
\text { analogous to slavery. M. Officer clothes } \\
\text { were being made at the location. } \\
\text { Bolivian workers were found, living } \\
\text { with their children on-site, and worked } \\
\text { in inhumane conditions. The factory did } \\
\text { not have sanitation, nor a place to eat. } \\
\text { Employees paid for housing and } \\
\text { household expenses by having those } \\
\text { expenses discounted from their } \\
\text { payments. The company was fined and } \\
\text { sued for debt servitude and exhausting } \\
\text { workdays. In the same year, eight other } \\
\text { companies were also filed for } \\
\text { contemporary slavery labor: Le Lis } \\
\text { Blanc, Bo. Bô, Hippychick, Cori, Emme, } \\
\text { Luigi Bertolli, Fenomenal, and Gangster. }\end{array}$ & $\begin{array}{l}37 \text { Bolivians were rescued from } \\
\text { a manufacturing unit owned by } \\
\text { Renner in November } 2014 \text {. The } \\
\text { factory was located in the } \\
\text { outskirts of São Paulo and } \\
\text { offered conditions similar to } \\
\text { slavery to its employees, who } \\
\text { lived in a degrading situation } \\
\text { and worked long and exhausting } \\
\text { shifts. According to reports, they } \\
\text { were also in debt servitude. In } \\
\text { the same year the companies } \\
\text { Unique Chic, As Marias, Seike } \\
\text { and Atmosfera were also filed } \\
\text { for contemporary slavery labor. }\end{array}$ \\
\hline
\end{tabular}

Source: Adapted from Batista (2018, p. 90). 
As noted in the previous table, between 2010 and 2014, issues regarding work analogous to slavery are very present in Brazil. Thus, it is of utmost importance that these cases are brought up to encourage society to reflect on the conditions of workers in the country's textile industry.

In this sense, we can see in the following figure some manufacturing facilities where precarious working conditions are observed.

Figure 1. Manufacturing units found in Brazil with inhumane conditions.
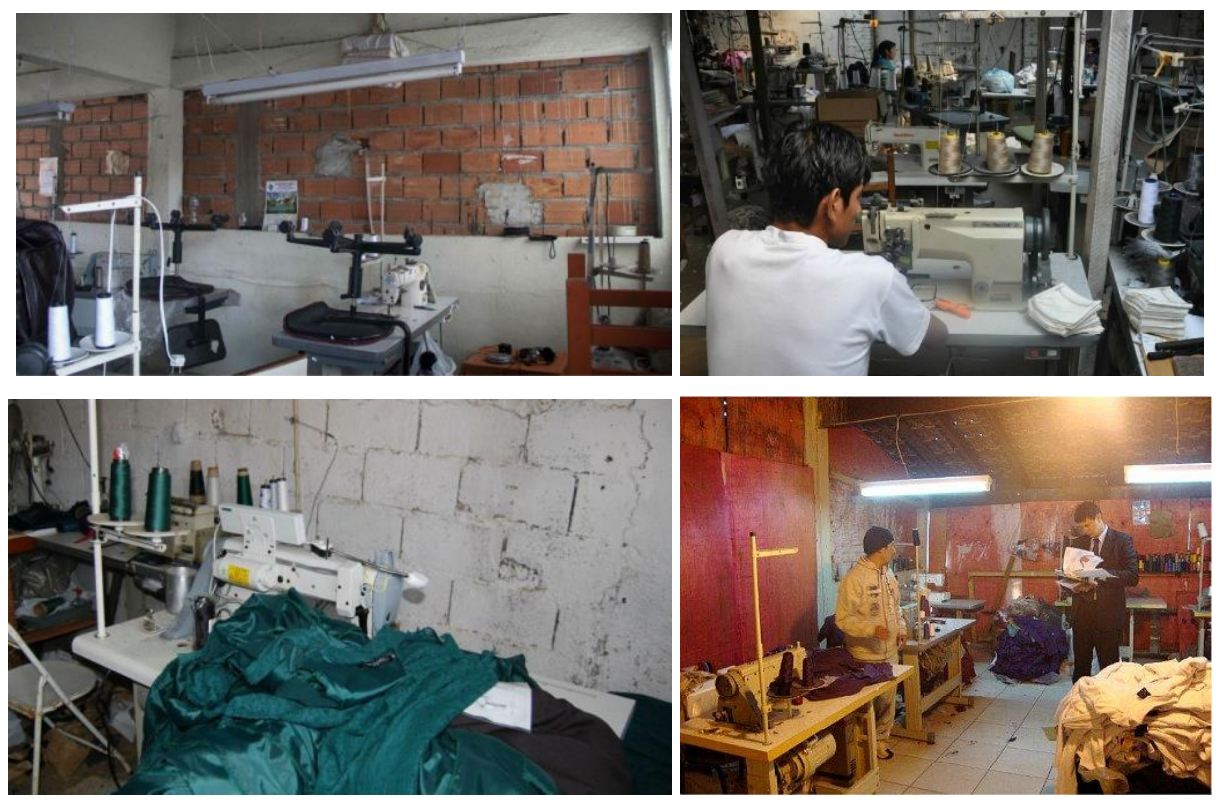

Source: https://reporterbrasil.org.br/2012/07/especial-flagrantes-de-trabalho-escravo-na-industria-textil-no-brasil/

It is well known that societies experience humanitarian crises often. In this sense, as highlighted by Borba \& D'Angelo (2020), a high number of migrants and refugees, aiming to evade wars and misery, are looking for new locations, especially in countries that are essentially democratic. In this respect, many people see in Brazil an opportunity to re-establish their lives but end up being taken to precarious jobs, with working conditions analogous to slavery.

Not so far from the cases mentioned in the previous table, according to the website Repórter Brasil (2020), amid the COVID-19 pandemic that affects several countries, including Brazil, those discussed issues in the textile industry continue to happen. The website said that foreign seamstresses spent two months 'confined' in a sewing manufacturing unit, working 14 hours a day and being paid less than the minimum wage. The article also stated that the seamstresses were conditioned to various types of suffering, both physical and verbal violence and that they did not have the bare minimum to live a dignified life. The workers were locked in the building that served as both their houses and their workspace and had exhausting workdays. In an interview for the website, auditors in the case said that the unit's owners used the coronavirus crisis to prevent young women from leaving the place. Coercion is common, and now the pandemic server as an excuse for the worker's confinement. The case was notified and the suspects were arrested and fined, while the employees were directed to competent authorities (Repórter Brasil, 2020).

Amid these various inhuman and precarious forms of work, fortunately, some actions seek to somehow control or eradicate such practices; thus, a series of measures have been taken in recent years to (attempt to) modify this situation.

According to Miraglia, Hernandez, \& Oliveira (2018), there has been a strong and necessary inspection in recent years, which helps fight against labor practices that can be characterized as analogous to slavery. The authors say that, between the years of 2010 and 2018, more than 37 companies were fined for offering their workers inhumane and precarious conditions 
at work, all thanks to the work and investigation of competent bodies and authorities.

The Pact for Decent Work in the Clothing Manufacturers of São Paulo (translated by the authors) - elaborated in 2009, is another measure that allows inspections on the work conditions in sewing workshops and manufacturing units in the city of São Paulo. These are collective efforts between civil society, unions, politicians, and public institutions that aim to raise awareness about the problem and hold clothing brands accountable for the work conditions they offer to their employees in their production chain. This way, said efforts are an important mechanism that can be used to eradicate contemporary slavery labor.

It is also important to highlight the work and inspections carried out by the Brazilian Ministry of Labor and Employment (MTE) and the Public Ministry of Labor (MPT) to combat precarious work and work analogous to slavery, through measures and laws that curb such practices. It is also worth mentioning the elaboration of the 'dirty list' (lista suja), which is a means of publicizing companies that use some kind of inhumane work.

The importance of other forms of organizations that help assist in reports and denunciations related to precarious work practices, such as the NGO 'Repórter Brasil' and the 'Moda Livre' mobile app, that establish themselves, especially in this technological age, as mechanisms of paramount importance and relevance to society.

\section{Conclusion}

Through globalization processes, we highlight the restructuring of the production chains (in several fields) that has consequently promoted a series of mechanisms that have been deliberately exploiting jobs, such as outsourcing, overtime, flexible and precarious work environments, as well as other actions that tend to hinder integrity in the fashion production chain. Therefore, through this research, we can critically reflect on the existence of work analogous to slavery - and its precariousness - in the fashion and clothing industry in Brazil.

Fortunately, the results of this study pointed to actions that aim, as far as possible, to raise awareness and monitor the realities of the fashion production chain. Thus, the social realities of these individuals are highlighted, seeking to avoid, raise awareness, and educate society about human exploitation, in order to encourage and inspect companies seeking greater transparency in the fashion production chain.

Furthermore, these brief explanations about the working conditions in the textile industry show us that, although discussions about this practice are happening, it is still present in several spheres in society. These are inhumane practices that exploit individuals at different levels. Therefore, it is our responsibility, as a society, to report those practices and demand from competent authorities and bodies a more diligent inspection and the application of the appropriate punishments.

As future work possibilities, it is interesting to think about the issue of precarious work conditions in the textile industry in the context of the COVID-19 pandemic, considering that, based on the results pointed out during this research, this imposed social condition exacerbates the issues regarding the dehumanization found in this field.

\section{References}

ABIT. (2019). Perfil do setor. Associação Brasileira da Indústria Têxtil e de Confecção: https://www.abit.org.br/cont/perfil-do-setor

Antunes, R. (2009). Os sentidos do trabalho: ensaio sobre a afirmação e a negação do trabalho. Boitempo.

Antunes, R., \& Druck, G. (2015). A terceirização sem limites: a precarização do trabalho como regra. O Social Em Questão, 18(34), 19-40.

Barros, S., Rosa, F., \& Ribeiro, E. M. (2017). Princípios e técnicas para elaboração de textos acadêmicos: pensando na pós-graduação. UFBA.

Batista, F. E. A. (2018). A moda que não sai de moda: o trabalho nas confecções têxteis brasileiras. Falange Miúda, 2(1), 87-92. http://www.falangemiuda.com.br/index.php/refami/article/view/77 
Research, Society and Development, v. 10, n. 1, e11510110841, 2021 (CC BY 4.0) | ISSN 2525-3409 | DOI: http://dx.doi.org/10.33448/rsd-v10i1.10841

Borba, C. da C. M., \& D'Angelo, I. B. de M. (2020). The capitalist system in the context of migrant and refugee workers: the sisyphus myth. Research, Society and Development, 9(1), e169911826. doi:10.33448/rsd-v9i1.1826

Duarte, G. G. (2015). O fast-fashion e o fator humano: uma abordagem para a conscientização da produção e do consumo e eliminação do trabalho escravo contemporâneo. Anais do $11^{\circ}$ Colóquio de Moda.

Gil, A. C. (2008). Métodos e Técnicas de Pesquisa Social (6th ed.). Atlas.

Godoy, A. S. (1995). Pesquisa Qualitativa: tipos fundamentais. Revista de Administração de Empresas, 35(3), 20-29. 10.1590/S0034-75901995000300004

Harvey, D. (2010). A condição pós-moderna (19th ed.). São Paulo: Loyola.

Manduca, M. L. G., \& Navarro, L. A. (2019). O trabalho análogo à condição de escravo no setor têxtil brasileiro. Boletim Jurídico, 31(1673). https://www.boletimjuridico.com.br/artigos/direito-do-trabalho/4646/o-trabalho-analogo-condicao-escravo-setor-textil-brasileiro

Miraglia, L. M. M., Hernandez, J. do N., \& Oliveira, R. F. de S. (2018). Trabalho escravo contemporâneo: conceituação, desafios e perspectivas. Lumen Juris.

Motta-Roth, D., \& Hendges, G. R. (2010). Produção textual na universidade. Parábola.

Refosco, E., \& Pessoa, J. (2013). A terceirização nas indústrias de vestuário. $9^{\circ}$ Colóquio de Moda, 1-12.

Repórter Brasil. (2019, december). Pacto Pelo Trabalho Decente nas Confecções de São Paulo Completa 10 Anos. https://reporterbrasil.org.br/2019/12/pactopelo-trabalho-decente-nas-confeccoes-de-sao-paulo-completa-10-anos/

Repórter Brasil. (2020, june). Trabalho escravo, despejos e máscaras a R\$0,10: pandemia agrava exploração de migrantes bolivianos em SP. https://reporterbrasil.org.br/2020/06/trabalho-escravo-despejos-e-mascaras-a-r-010-pandemia-agrava-exploracao-de-migrantes-bolivianos-em-sp/

Santos, S. D. M. dos. (2017). Entre fios e desafios: indústria da moda, linguagem e trabalho escravo na sociedade imperialista. RELACULT - Revista LatinoAmericana de Estudos em Cultura e Sociedade, 3. 10.23899/relacult.v3i3

Silva, A. A. B., \& Silveira, W. H. A. (2018). Análise do Trabalho Escravo nas Grandes Magazines: uma leitura moderna acerca do novo modo de exploração. Scientia Iuris, 22(1), 223-257. 10.5433/2178-8189.2018v22n1p223 